This article was downloaded by: [b-on: Biblioteca do conhecimento online UL] On: 31 August 2015, At: 06:13

Publisher: Routledge

Informa Ltd Registered in England and Wales Registered Number: 1072954 Registered office: 5 Howick Place, London, SW1P IWG

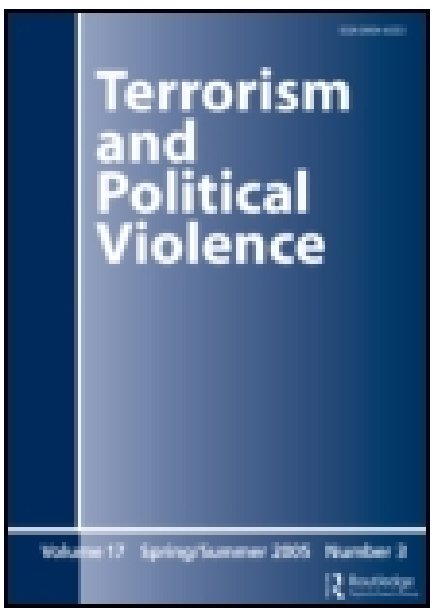

Terrorism and Political Violence

Publication details, including instructions for authors and subscription information:

http:// www. tandfonline.com/loi/ ftpv20

\title{
Martin A. Miller. The Foundations of Modern Terrorism: State, Society and the Dynamics of Political Violence
}

\author{
J osé Pedro Zúquete ${ }^{a}$ \\ a University of Lisbon, Lisbon, Portugal \\ Published online: 11 Aug 2015.
}

\section{CrossMark}

\section{Click for updates}

To cite this article: J osé Pedro Zúquete (2015) Martin A. Miller. The Foundations of Modern Terrorism: State, Society and the Dynamics of Political Violence, Terrorism and Political Violence, 27:4, 786-788, DOI: $10.1080 / 09546553.2015 .1068094$

To link to this article: http:// dx. doi.org/ 10.1080/09546553.2015.1068094

\section{PLEASE SCROLL DOWN FOR ARTICLE}

Taylor \& Francis makes every effort to ensure the accuracy of all the information (the "Content") contained in the publications on our platform. However, Taylor \& Francis, our agents, and our licensors make no representations or warranties whatsoever as to the accuracy, completeness, or suitability for any purpose of the Content. Any opinions and views expressed in this publication are the opinions and views of the authors, and are not the views of or endorsed by Taylor \& Francis. The accuracy of the Content should not be relied upon and should be independently verified with primary sources of information. Taylor and Francis shall not be liable for any losses, actions, claims, proceedings, demands, costs, expenses, damages, and other liabilities whatsoever or howsoever caused arising directly or indirectly in connection with, in relation to or arising out of the use of the Content.

This article may be used for research, teaching, and private study purposes. Any substantial or systematic reproduction, redistribution, reselling, loan, sub-licensing, systematic supply, or distribution in any form to anyone is expressly forbidden. Terms \& 
reader who does not need to parse so finely the ambitions and internecine conflicts that terrorism scholars rely upon to distinguish terrorist actors. Individuals well acquainted with terrorism scholarship and practice will likely protest Nester's work as an oversimplification of the geopolitical, diplomatic, and doctrinal considerations that factor into how terrorist threats are prioritized and countered.

Nester makes a political argument. As a contribution to public debate on the appropriate use of national power, Nester's ideological filter can be considered a strength. Hearts, Minds, and Hydras is less worthy as a contribution to debate within terrorism studies, however, in which politics and personalities are bracketed outside analysis, or introduced as variables in a methodological calculus. Nester's opinionated analysis may strike the public as forthright, but it simultaneously raises concerns about selective bias. Nonetheless, Nester maintains his credibility and offers readers a valuable reminder that national decisions are made by people who have deeply ingrained and personal motivations that affect their world view.

Hearts, Minds, and Hydras introduces a number of topics in terrorism studies. Nester swiftly covers terrorists as rational actors; old and new terrorism; paths to radicalization; foreign fighters; the labeling of terrorism as a criminal act versus an act of war; the battle of ideas and ideologies; the role of the media and Hollywood; and policy choices among conquest, containment, and deterrence. Nester serves up these tapas as a full meal that leaves the casual reader satiated.

Hearts, Minds, and Hydras is written for an audience interested in the politics that drive the global war on terrorism. The book is unlikely to satisfy one's curiosity on its own, leaning more toward breadth than depth. Because Nester's argument invites a comparison with other authors' viewpoints, Hearts, Minds, and Hydras is most valuable as part of a general collection representing a more complete chronology, with assessments of Obama Administration policies and a wider spectrum of political thought.

Martin A. Miller. The Foundations of Modern Terrorism: State, Society and the Dynamics of Political Violence. Cambridge, UK: Cambridge University Press, 2013. 292 pp., \$29.99 paperback. ISBN: 978-1-107-62108-4.

\author{
Reviewed by José Pedro Zúquete \\ University of Lisbon \\ Lisbon, Portugal
}

In the well-written The Foundations of Modern Terrorism, Duke University historian Martin A. Miller provides a revisionist overview of the history of terrorism and its literature - both in favor of the need to stress the interplay between the state and insurgencies in the analysis of the phenomenon and against the dominant tendency to focus on insurgents' violence (always illegitimate) rather than on state violence (viewed as legitimate counterterrorism). These main themes are put forth in the first and last chapters, while in between, and throughout different historical periods, the author condenses them into "a single narrative format" (p. 2), illuminating all the 
dynamics of what he calls the "synchronic dialogue" (p. 9) in history between state and insurgent violence.

This narrative of this struggle over the legitimacy of power opens with a brief look at the pre-modern era, particularly the development since the Greco-Roman period of the concept of the right of resistance to despotism, as well as the discourse on tyrannicide, which, continuing through Catholic and Protestant theologies, left a defining mark in the foundations of terrorism. The French Revolution would take state violence ("Revolutionary Terror") — and the defense of the legitimacy of violence by the state - to unprecedented heights, and the Restoration period that followed ("White [royal] Terror") was characterized itself by repression and the widespread increase in the apparatus of state surveillance all over Europe. The description - in perhaps what is the strongest chapter-of "Nineteenth-century Russian Revolutionary and Tsarist Terrorisms" and of the decades-long fight between the police and a radical underground of insurrectionary terrorists reveals the "mirror-like quality of their respective modes of operation" (p. 94). After the destruction of the Paris commune-a "moment of unbridled state terror" (p. 102) - an Anarchist-inspired wave of "insurgent terror" surfaced in Western Europe and the U.S. that, for the first time, broke the boundaries between attacks against officials and society at large (p. 112), and led to increased cooperation between police and intelligence services across borders with the aim of preventing the transnational circulation of Anarchists. This situation lasted until the Great War. What follows is a broad look (roughly 60 pages) at, first, "Terrorism in a Democracy: The United States"-in which, the author says, the legal system at a national and local level legitimized political violence against Native Americans and African Americans - and secondly at terrorism in authoritarian and totalitarian inter-war regimes, from the "Red Terror" in Soviet Russia (and its consequences in the U.S.) to the "Brown Terror" in Weimar and Nazi Germany, ending with the program of state terror of Stalinism (also with its "literary terrorism" and war against poets and writers). This historical incursion into the history of terrorism ends with the "Global Ideological Terror during the Cold War," whether related to colonial and post-colonial struggles (Congo, Algeria, and South Africa), Latin American campaigns of state terror against Communist armed guerrillas and political insurgencies (with some of the most brutal conflicts of the period), as well as political violence in the U.S. (by Left-Wing and Black Power groups, Right-Wing militias, and state repression through the FBI) and in Western Europe, particularly Left-Wing terrorist groups in Germany, and "Red Terror" and "Black Terror" (Neo-Fascist) assassination and bombing campaigns in Italy. Throughout global ideological terror, the author argues, "the trajectories of political violence at the level of both governments and insurgencies remained inextricably intertwined" (p. 239). The concluding chapter, as noted, reaffirms the revisionist (p. 253) position on the study of terrorism that integrates the "historic antagonists" (state and insurgents) while noting, almost despondently, the overwhelming presence of political violence in our contemporary societies, especially since the open-ended and utopian Declaration of the Rights of Man that served to intensify the question of and debate over the legitimacy of political power for the foreseeable future (p. 256).

Miller has written a highly informative and instructive work that is especially recommended to students of history, sociology, international relations, and all introductory courses on terrorism and its many facets. Obviously, in such a wide-ranging book, it is almost unfair to focus on what is missing in the inevitably broad look of 
each historical period. More important is to establish whether or not a number of contemporary terrorist (or would-be terrorists) groups - particularly those who share a global imaginary, whether secular or religious, against modern civilization — still perceive their major antagonist to be state power, with its agents and infrastructures. Although they often act locally, they target a global enemy, whether it be capitalism or Western Civilization, for example, that extends far beyond the boundaries of each nation-state. This trend is present, for instance, in a 2007 Left-Wing French revolutionary manifesto, "The Coming Insurrection," which identifies as its enemy capitalism and all its ramifications, not the French state. Also, a look into the ideology of the Islamic State of Iraq and Syria (ISIS) reveals that their end goal is an Islamic order in which the camp of the blessed, or righteous ummah, overrides all other identities (including nationalities) and is brutally opposed to the "cursed," which is not a state, or even a combination of states, but fundamentally all those associated with a godless world. Maybe these transnational dynamics, whether of a secular or religious nature, also merit inclusion in the study of political violence and all its manifestations in the early twenty-first century.

Cynthia C. Combs. Terrorism in the Twenty-First Century, 7th ed. Upper Saddle River, NJ: Pearson, 2012. 416 pp., \$75.95 paperback. ISBN: 978-0-2058-5165-2.

\author{
Reviewed by Kai Chen \\ Xiamen University \\ Xiamen, Fujian Province, China
}

The book under review is the seventh edition of Terrorism in the Twenty-First Century - a popular textbook and source for teaching on contemporary terrorism. It succeeds in demonstrating that contemporary terrorism is less politically oriented to a large degree, and exploring the extent to which terrorism in the twenty-first century is different from its counterparts in history.

This book features fifteen chapters, which address the most critical aspects of contemporary terrorism, such as the evolution and ideology of terrorism, categories of terrorists, how different terrorists operate, countermeasures to terrorism, current governance of terrorism, and the future prospect of counterterrorism. It's written in a way that is highly accessible for readers who do not have prior knowledge of contemporary terrorism.

As a long-lasting textbook and source for teaching, Terrorism in the Twenty-First Century is based on the moral rightness that "terrorism is a crime, in any context, for any cause" (p. 378). It's noteworthy that this book advances a working definition of terrorism, that is, "actions intended to destroy innocent persons, when motivated by political objectives and designed to create a mood of fear in an audience" (p. 374). In the meantime, this book reveals a formidable tactic adopted by terrorists - improvised explosive devices, "a homemade device designed to cause death or injury by using explosives alone or in combination with other materials" (p. 146), which is more predictable than the tactics adopted by terrorists in early years. Moreover, as the author highlights, one of the applicable solutions to terrorism is to track and cut terrorists' funding, which can "disrupt the logistical and 